\title{
Tax Law Enforcement in Strengthening Tax Compliance Behavior of Individual Taxpayers
}

\author{
Edrick Purnama Putra and Heru Tjaraka \\ Business and Economics Faculty, Universitas Airlangga, Surabaya \\ Email: edrick.Purnama.Putra-2016@feb.unair.ac.id; heru_tjaraka@feb.unair.ac.id
}

\begin{abstract}
The main problem of taxation in Indonesia still revolves around the tax compliance level, which is low, the problem of tax compliance is a classic problem faced by almost all countries. Departing from the general taxation problem, this study specifically examines taxpayers in Central Kalimantan, specifically in Palangkaraya. The research questions raised are whether the interaction between tax awareness and tax law enforcement impact on strengthening taxpayer compliance behavior. Second, whether the interaction between trust in tax authority and tax law enforcement has an impact on strengthening taxpayer compliance behavior. The test results show that both tax awareness and trust in tax authority have a positive influence on the taxpayer obedient behavior. The tax law enforcement moderation variable is tested to be a moderation variable that reinforces the taxpayer's compliance behavior. In the final section we offer conclusions, contributions, and implications, including suggestions for further research.
\end{abstract}

Keywords: tax law enforcement and compliance behavior.

\begin{abstract}
Abstrak: Masalah utama perpajakan di Indonesia masih berkisar pada tingkat kepatuhan pajak, yang masih sangat rendah, masalah kepatuhan pajak adalah masalah umum yang dihadapi oleh hampir semua negara. Berangkat dari masalah perpajakan umum, penelitian ini secara khusus memeriksa wajib pajak di Kalimantan Tengah, khususnya di Palangkaraya. Pertanyaan penelitian yang diajukan adalah apakah interaksi antara kesadaran pajak dan penegakan hukum pajak berdampak pada penguatan perilaku kepatuhan wajib pajak. Kedua, apakah interaksi antara kepercayaan pada otoritas pajak dan penegakan hukum pajak berdampak pada penguatan perilaku kepatuhan wajib pajak. Hasil pengujian menunjukkan bahwa baik kesadaran pajak dan kepercayaan pada otoritas pajak memiliki pengaruh positif pada perilaku kepatuhan wajib pajak. Variabel moderasi penegakan hukum pajak diuji menjadi variabel moderasi yang memperkuat perilaku kepatuhan wajib pajak. Pada bagian terakhir kami menawarkan kesimpulan, kontribusi, dan implikasi, termasuk saran untuk penelitian lebih lanjut.
\end{abstract}

Kata Kunci: penegakan hukum pajak dan perilaku kepatuhan.

\section{INTRODUCTION}

The issue of tax compliance is a classic problem faced by almost all countries thatimplement a taxation system (Onwuka et al., 2019). The main problem of taxation in Indonesia is still ranging from the tax compliance level which is still very low (Panjaitan et al., 2018). The tax compliance level in Indonesia is still low, with only 30 percent of the 
taxpayer paying the tax. When compared with the fulfillment of tax payments in Malaysia, which has 80 percent of registered taxpayers, of course, Indonesia's tax performance is still far behind (Panjaitan et al., 2018). Tax is a mandatory contribution to the state owned by an individual or legal entity that is compelled under the law, without direct compensation, and is used for the country's need for the amount of prosperity of the people (UU No. 6 1983). Compliance with taxpayers is defined as the taxpayer's behavior in carrying out all tax obligations and exercising their tax rights while complying with the laws and regulations (Marjan, 2014). Low levels of tax compliance are central to the Government's attention because non-compliance of taxpayers can cause tax evasion intent or deliberately unwilling to pay a tax obligation. This behavior indirectly causes a decrease in tax revenue received by the state. Taxpayers must have tax knowledge.

According to (Melando and Waluyo, 2013) essentially taxpayers carry out tax obligations because they have adequate tax knowledge. Perception of the effectiveness of the taxation system that affects the taxpayer's awareness in paying taxes (Indrawan, 2014). The Directorate General of Tax of the Republic of Indonesia provides taxpayer knowledge to know about taxation, regulations and tax procedures (Saragih, 2013). The dissemination of tax information from counseling and advertising includes dissemination of information about the taxpayer's rights and obligations. According to (Sugeng, 2012) A promotional tax is an effort that can be taken to raise taxpayer awareness and compliance.

The selection of Media that can be accepted by taxpayers is important in socialization activities (Herryanto, 2013). (Lianty et al., 2017), the results showed a lack of awareness and understanding of Indonesian people to comply with tax payments. Tax awareness can be measured by the rate of tax ratio (Sucipto, 2016). In tax there is an element of compulsion as an effort to realize tax revenues. It can be interpreted that as citizens are forced to voluntarily fulfill their tax obligations, this is what is called tax compliance. According to (Tiraada, 2013), the fulfillment of tax obligations made by taxpayers to contribute is expected to be made voluntarily. Taxpayers are said to be obedient when they have fulfilled all of their tax obligations (Nurmantu, 2005). The fulfillment of taxpayers in the fulfillment of tax obligations is a factor that affects the country's tax revenue, they can increase the tax ratio (Nurmantu, 2005).

(Muliari and Setiawan, 2011) stated that tax awareness is required because taxes serve as state funds so that taxpayer compliance can be increased. The knowledge of tax payments has a positive impact on the taxpayer's compliance, the research results show a positive relationship between taxpayer awareness and compliance with personal taxpayer reporting. This study develops taxpayers ' awareness and trust in the community's authority by using tax law enforcement as a mediating variable and its impact on taxpayers ' compliance.

\section{THEORETICAL REVIEW}

Tax Compliance Framework. Tax compliance includes the understanding of justice, efficiency and incidents. Wenzel in, (Muthaloo et al., 2020) argued that the research on tax compliance has been dominated by economic analysis, which framed the taxpayer's decision to pay or not to pay taxes as a rational individual effort to maximize profits (Alventosa and Olcina, 2019). According to Gibson in (Macphee et al., 2012), the definition of obedience is the motivation of a person, group or organization to act or not 
act according to the stipulated rules. Taxpayer compliance is a public awareness to fulfill their tax obligations (McKee et al., 2018). Tax compliance is a worldwide government concern (Wijaya and Effendi, 2020). Therefore, the traditional economic tax compliance model primarily emphasizes on variable enforcement and detection. However, the conventional economic tax compliance approach is not able to comprehensively describe the current level of compliance in developing countries such as Uganda. Recent research, however, supports the claim that non-economic, socio-psychological factors (e.g., ethics, perception of justice, social norms and psychological reactions) also influence the behavior of paying taxes (Wijaya and Effendi, 2020; (Blaufus et al., 2013; Wang et al., 2020).

The economic researchers who studied tax compliance (Novianti and the goddess, 2017) have called for more attention to the social psychological influence on tax compliance. Economists, in particular, have focused on the concept of "social norms" (Guerra, and Harrington, 2018; Muthaloo et al., 2020). However, most of these economic studies do not determine exactly what this social norm is; Instead, they model variables that affect compliance in a manner that is consistent with the substantial effects of some outside social influences.

Baldry in (Garcia et al., 2020) argue that moral rules determine taxpayers compliance, but perceived sentiment is perceived. A taxpayer may incur a moral charge if he or she does not pay taxes and acts as a free rider. (Elffers, 2000), attempts to show that it is still long before someone becomes a tax giver. He defines three steps on the stairs to avoid taxes. First, taxpayers must be seized by disobeying. In the second step, Elffers convey that taxpayers with a tendency not to pay taxes should not materialize in the form of tax evasion action. In step three, found taxpayers who feel less inclined to obey and examine opportunities to avoid taxes. Elffers This third phase is the phase in which the standard economic theories play a role, where taxpayers evaluate the benefits gained from having to avoid taxes.

Research into taxpayers ' compliance (Alventosa and Olcina, 2019) describes the legal implications factor, including tax agent investigations considered in compliance decisions. The decision to pay taxes accurately or deduct the amount of tax they paid after the investigation was not made. (Alventosa and Olcina, 2019) Further discuss the policy instruments to eliminate tax evasion, such as "tax rate, penalty level, and probability of detection ". Taxpayers will comply with tax obligations if the weight penalty rules apply compared to the benefits obtained. This legal factor is a psychological factor for taxpayers. (Suh et al., 2019).

(Luttmer and Singhal, 2014) Identify the role of moral taxation, which stems from the conviction of tax compliance originating from the WP-payer himself. In addition, psychological aspects, including public involvement as taxpayers with the government, can create an intention to comply with taxes and make real tax reports in tax payments (chan et al., 2017). The results of the study showed slippery slope slope and tax compliance paradigm shifts. All factors may be categorized as. Voluntary or enforcement approaches; B. Prevention or psychological factors-as a factor that affects the behavior of taxpayers ' compliance. (Kogler et al., 2013) examined the relationship between trust and power in influencing tax-compliant behavior at the state level. (Kogleretal., 2013) connecting further between economic and psychological factors as an effort to expand the factors affecting tax compliance. (DeVos, 2013) considers that the study of the inability to 
impact prevention efforts against taxpayer compliance, therefore, is necessary to include psychological factors in the research model. Other researchers, (Birds and Davis, 2018) included elements of sanctions and legal aspects in accordance with the tax law.

The tax compliance framework used in this study to analyse the perspective of compliance with taxes in Siem Reap Province, Cambodia, almost entirely adopted the (Devos, 2013), which combines elements of psychological economics and social prevention. He included "Punishment, tax enforcement, probability detection, tax payer moral, and taxpayer awareness ". However, current case analysis requires additional critical-trust factors in the tax authority-adopted from Kirchler in (Blaufus et al., 2013). The slick slope framework focuses on institutional and psychological factors (Blaufus et al., 2013). The case study in Siem Reap combined institutional and psychological factors into tax compliance frameworks to analyse central taxpayers ' compliance and to find their perception of the implementation of tax policy.

Law enforcement over taxes. Law plays an important role in implementing policy. Regardless of their background, people must comply with laws and regulations. Tax compliance is enhanced using voluntary and enforced approaches (Blaufus et al., 2013). Turner in (Youde and Lim, 2019) explained that the law is the authority of tax officials with the "compulsion and force of law" to carry out income collection. Therefore, legally, the tax authorities have the power to increase compliance with taxes. They also have the authoritative power to legally punish the illegal reductions in tax payments by conducting tax audit activities and imposing penalties. The absence of strict laws will cause the tax system to operate ineffective (Bird and Davis, 2018).

However, (Ali and Ahmad, 2014) reported that audit and audit obligations would be reduced after large levels of tax compliance were maximised. Accordingly, the Tax Amendment ACT (2004), section 93, states that the tax authorities have the legal force to collect tax revenues and impose penalties if tax laws are violated. In order to achieve increased tax compliance, the tax administration should be given sufficient force to carry out its supervisory and audit role by imposing the penalty for tax evaders (Ali and Ahmad, 2014). Tax officials also have the authority to educate taxpayers through voluntary approaches. Kirchler at (Blaufus et al., 2013) Measures tax compliance based on the taxpayer's point of view on the power of authority and their belief in authority within the slippery slope framework. They found that the power of authority increased obedience. Increasing the power of authority is the enforcement approach.

According to (Slemrod and Bakija, 2017), if the role of the Internal Revenue Service (IRS) in the US does not exist, the free rider will continue to ignore their taxable obligations, while the compliant taxpayers will still pay their tax obligations, indicating that the competent role authorities played by the IRS legally protect the legal taxpayer from being utilized by tax evaders or free racers.

Tax awareness. Li et al defines a taxpayer awareness as "... The behavior or attitude of an object involving assumptions and feelings and a tendency to act on that object "(Lianty et al., 2017). The taxpayer's awareness in fulfilling tax taxation obligations in paying taxes is influenced by mutual knowledge, trust and reasoning will act in accordance with the rules given by the taxation system and provisions (Alhempi et al., 2020; Muliari and Setiawan; Castro and Scartascini, 2015). Requirements that must be owned by the taxpayer who is 
categorized as having tax awareness is to know the provisions of taxation, know the function of taxation, understand the obligations of taxation, understand the function of taxation (Muliari and Setiawan, 2011). Taxpayer awareness is based on taxpayer knowledge about taxation mechanisms and taxation regulations, including applicable regulations including data on tax payments and types of tax obligations, tax rates and tax exemption.

As such, taxpayers ' education is an effective instrument to increase tax compliance (Wijaya et al., 2020). Voluntary from taxpayers in paying different types of taxes. This is the contribution of their citizens. For example, state revenues from land taxes and buildings are used for local government needs. Tax education can provide taxpayer information so they have more knowledge and consequently comply with the tax law. (Kamil, 2015) resulted in a strong correlation between taxpayers ' compliance and awareness. Research conducted by (Chan et al., 2017) found that positive tax awareness was related to tax morals, increased moral taxes and could reduce the intent of tax evasion. Research conducted by (Devos, 2013) shows that there is a positive and significant relationship between tax awareness and compliance.

Development hypothesis. Compliance is a taxpayer's awareness is a community effort (taxpayer) to fulfill the tax obligations (McKee et al., 2018), which includes having a taxpayer identification number (NPWP), sending the notification letter correctly and completely, ultimately paying the obligation on time. Taxpayer compliance indicator is tax rate calculation, timely payment, tax reporting, obtaining NPWP. This measurement develops a measurement of taxpayer compliance. This measurement develops the measurement of taxpayers ' compliance (Nashwan et al., 2020).

(Li et al., 2018) defines a taxpayer awareness as "... Behavior or attitude of an object involving assumptions and feelings and a tendency to act on that object ". The awareness of taxpayers is a taxpayer's behavior in acting in the form of a view involving interactions between. Knowledge, B. Trust, and C. Common grounds with a tendency to act in accordance with taxation rules, (Muliari and Setiawan, 2011; Castro and Scartascini, 2015). The requirements for people with tax awareness are: understand the taxation provisions, understand the taxation function, understand the tax obligations, understand the benefits of taxation (Muliari and Setiawan, 2011). Based on the concept of subjective norms of belief in the planned behavioral theory (TPB), the taxpayer conduct whether they fulfill the tax obligations with the value of trust. The values believed to be sourced from the environment where taxpayers are located or derived are often referred to as social norms (Vamvaka et al., 2020).

Law of perspective or enforcement approach, violation of taxation obligations, provided that the threat of sanctions, either through the threat of fear of possibility of being examined and then subject to taxation sanctions, will force the taxpayer to fulfill their obligations.

Hypothesis: (1) Tax law enforcement will strengthen the relationship between tax awareness and tax compliance behavior. (2) Enforcement of tax law will strengthen the relationship between trust in tax authorities as well as tax compliance behavior. 


\section{Model Analysis}

The analytical Model in this study is presented as follows:

Figure 1. Analysis Model

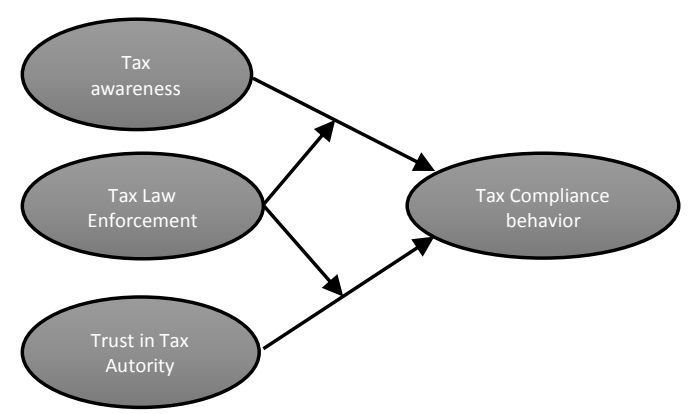

\section{METHODOLOGY}

The research uses a quantitative approach that focuses on hypothesis testing with statistical analysis tools and results in a generalized conclusion. The assumption used in this study is in the form of variables that can be measured and useful to explain the reciprocal relationship (causality) that begins with hypotheses and theories.

Variable measurements. The dependent variables used in this study are tax compliance behaviors. The tax compliance framework in this study has one variable of outcome-tax compliance perspective, which is measured by the intention to comply and participate in taxation. A tax compliance perspective of intermediate taxpayers is handled by two survey questions. Modified from (Ali and Ahmad, 2014). Law enforcement tax can be determined by 5 items-adopted from (Devos, 2013) -which is answered with 5 point Likert scale points $($ not very important $=1,($ disagree $)=2,($ enough $)=3,($ agree $)=4$, and $($ very concur = 5); One item, for example, "The strategy used to increase tax is to increase the audit amount" (Devos, 2013). The awareness of taxpayers with five items, which are answered on a five-point Likert scale (do not know $=1$, know a little $=2$, enough $=3$, know $=4$, very know =5). An example of an item to measure this variable is based on "Understand what determines tax evasion," agrees from (Devos, 2013); However, in items one and five are only designed for this question. Trust the tax authorities.

Acquired Slopey Slope frame and was used as an explanatory variable. It can be adapted to four items-adapted from (Gobena and Van Dijke, 2016) - at five point Likert scale points; Examples of goods believed to trust the tax authorities are "tax officials taking their jobs with professionalism and devotion" (P. 34).

Example plan. The population used is private taxpayers of the city of Palangkaraya. Some people who do this research are referred to as examples. The samples in this study were 116 individual taxpayers. Sampling was conducted in September-November 2019. The sampling techniques used are sampling purposes, with the requirement that an individual taxpayer has a NPWP and has made a tax refund in the last 2 years. 


\section{THE RESULTS OF STATISTICAL TESTS}

The tests in this study used some regression tools using moderate variables. The equation of the moderation regression is conducted to test tax law enforcement to strengthen the influence of taxation awareness and confidence in the manager's conduct against compliance behaviour with tax obligations. The moderation regression results are presented in the following table:

Table 1. Analysis results with moderation variables

\begin{tabular}{l|c|c|c|c}
\hline & B & Beta & t & Sig. \\
\hline Constant & 0.644 & - & 1.207 & 0.230 \\
\hline TA & 0.410 & 0.497 & 5.657 & 0.000 \\
\hline TTA & 0.383 & 0.479 & 3.804 & 0.000 \\
\hline TL & 0.543 & 0.545 & 3.562 & 0.001 \\
\hline TA*TL & 0.242 & 0.326 & 2.705 & 0.008 \\
\hline TTA*TL & 0.156 & 0.410 & 2.336 & 0.021 \\
\hline$R^{2}$ & \multicolumn{5}{|c}{0.398} \\
\hline
\end{tabular}

From the above data, the moderating regression equation model is obtained as follows:

$\mathrm{TCB}=0,644+0,410 \mathrm{TA}+0,383 \mathrm{TTA}+0,543 \mathrm{TL}+0,242$ Moderasi TA*TL $+0,156$ Moderasi TTA*TL + e

Constants $(\alpha)$ is the interpretation of TCB if TA, TTA, TL, TA * TL moderation and TTA $*$ TL moderation $=0$, indicating that if the dependent variable used in the research model is constant. The constant value of 0.644 indicates that if the awareness of variable taxes, trust tax authorities, tax law enforcement, TA * TL moderation and TTA * TL moderation with 0 , the tax compliance behavior variable is 0.644. Tax awareness regression coefficient 0.410 positive (Unidirectional) between tax awareness and tax compliance behavior. If the tax awareness increase by 0.410 , the tax compliance behavior will increase by 0.410 . These results indicate that as an increase in tax awareness, the behavior of tax compliance will increase and vice versa.

A regression coefficient of the tax confidence of authority 0.383 indicates a positive direction (Unidirectional) relationship between the Trust tax authority and the tax compliance behavior. If the tax Trust authority increases 0.383 , the tax compliance behavior will increase by 0.383 . These results indicate that the higher the trust in the tax authorities, the behavior of tax compliance will increase and vice versa. The law enforcement tax coefficient of regression 0.543 shows the direction of a positive relationship (unidirectional) between tax law enforcement and tax compliance behavior. If tax law enforcement increases by 0.543 , the tax compliance behavior will increase by 0.543 . These results suggest that the higher the tax law enforcement, the behavior of tax compliance will increase and vice versa.

The TA * TL moderation regression coefficient of 0.242 indicates the positive direction (Unidirectional) relationship between FY * TL moderation and the tax 
compliance behavior. If a FY 0.242 moderation increase *, the tax compliance behavior will increase by 0.242 . These results show that the higher the FY* moderation, the behavior of tax compliance will increase and vice versa. TTA * TL moderation regression coefficient of 0.156 indicates the positive direction (unidirectional) relationship between the TTA * TL moderation with the tax compliance behavior. If the moderation TTA * TL increases with 0.156 , the tax compliance behavior will increase by 0.156 . These results indicate that the higher the moderation of the TTA * TL, the behavior of tax compliance will increase and vice versa.

Test the classic assumption. According to Ghozali, (2016) in testing using Fit regression AIDS is required testing for normality with the intention to test two variables used in the normal distribution. Statistical examination of non-parametric KolmogorovSmirnov, the criterion for determining is if the value is significant $>0.05$ then data is usually distributed, and if the value is significant $<0.05$ then data is not usually distributed. The value of Asymp. SIG (2-tailed) value is $0.174>0.05$, it complies with the defined conditions, so it can be concluded that the

Test the next classic assumption is the multicolinearity aimed at testing the strength of the relationship between independent variables. If the relationship between independent variables is high, then the concentration of independent variables in affecting dependent variables will be low. To detect the presence or absence of multicolinearity in this regression model is to see the value of tolerance $>0.10$ and the value of the inflation factor variance (VIF) < 10 Which means there is no multicolinearity between independent variables in the regression model (Ghozali, 2016:103). Based on the results from the table above it can be seen that the calculation result of the tolerance value for each variable indicates that all independent variables have a tolerance value greater than 0.1 . The result of the VIF value calculation indicates that the independent variable has a VIF value of less than 10. So, it can be concluded that there is no multicolinearity between independent variables in some regression equations.

Heteroscedasticity tests aim to test whether in regression models there is a variance inequality of residue from one observation to another. It can be said heteroscedasticity measures the relationship between residues and dependent variables. When the relationship between the two is high, it indicates that the relationship between independent and dependency will be disturbed (low). A good regression Model is one that does not happen heteroscedasticity. If there are certain patterns, such as dots that form a certain pattern (widening and then narrowed) then know heteroscedasticity has occurred. If there are no obvious patterns, and the points are scattered above and below the number 0 (zero) on the $\mathrm{Y}$ axis, then there is no heteroscedasticity. This unbalanced pattern is meant by different values between one variance of residuals. The use of the calculation results of Spearman correlation can also be used to determine whether heteroskedacity occurs or not in the model.

Good Fit Test. Generally speaking, the feasibility of the model is determined by the value of the coefficient of determination (R2) that measures how far the ability of the model to describe the dependent variable. $\mathrm{R} 2$ is between zero and one. A small value of $\mathrm{R} 2$ means that an independent variable's ability to explain a restricted dependent variable. Table 1 shows that the coefficient of determination of $\mathrm{R}$ Square for some of the regression equations is 0.389 which means that the awareness of variable taxes, confidence in tax 
authorities, tax law enforcement, TA * TL moderation and TTA * TL Moderation can explain the compliance behavior of variable taxes to $38.9 \%$ while the remainder is $61.1 \%$ described by other variables outside the research variables.

This test aims to test the model (appropriate) Fit or not (Ghozali, 2016). F tests were conducted by viewing the significance of $\mathrm{F}$ at the output of the regression result with significance of $0.05(\alpha=5 \%)$. If the significance value is smaller than $\alpha$ then the hypothesis is accepted, which means that the regression model is suitable/feasible and vice versa. The value of $F$ is calculated from 14.565 with a significant of $0000<0.05$, which means that the awareness of variable taxes, trust in tax authorities, tax law enforcement, TA * TL moderation and with TTA * TL moderation simultaneously has a significant effect on the tax compliance behaviour, so the model stated worthy. T tests essentially show how far the influence of one individual independent variable is in explaining the dependent variables (Ghozali, 2016). The test is done by looking at the significance of each variable in the output of the regression result with significance $0.05(\alpha=5 \%)$. Decision making criteria is if the value of significance $>0.05$ then the hypothesis rejected To test the hypothesis in the study of estimates of standard coefficients and P-values for each coefficient can be seen in table 1 . The results of the hypothesis testing in table 1 can be explained based on the test results there is a tax awareness effect on tax compliance behavior that results in a positive coefficient of 0497 with a significant value of 0000 . Therefore, a significant value of $0000<0.05$, proved that tax awareness affects the behavior of tax compliance, so that the proposed hypothesis has support in this study.

Based on the test results there is the influence of trust in tax authority on tax compliance behavior resulting in a positive coefficient of 0479 with a significant value of 0.000 . Therefore, a significant value of $0.000<0.05$, it is proven that trust in tax authority influences tax compliance behavior, thus the proposed hypothesis has support in this study. Based on the test results there is the effect of tax law enforcement on tax compliance behavior resulting in a positive coefficient of 0545 with a significant value of 0.001 . Therefore, a significant value of $0.001<0.05$, it is proven that tax law enforcement has an effect on tax compliance behavior, thus the proposed hypothesis has support in this study.

Based on the test results there is a moderate effect of TA* TL on the tax compliance behavior resulting in a positive coefficient of 0.326 with a significant value of 0.008 . Therefore, a significant value of $0.008<0.05$, proved that TA * TL moderation has an effect on the tax compliance behavior, so that the proposed hypothesis has support in this study. Based on the test results, there is a moderate effect of TTA * TL on the tax compliance behavior that results in a coefficient of 0.410 positively with a significant value of 0.021 . Therefore, the significant value is $0.021<0.05$, proving that modifications of the TTA * TL affect the behavior of tax compliance, so that the proposed hypothesis has support in this study.

Taxpayer awareness as it involves knowledge, a crucial component in building awareness is to build an effective education for taxpayers. A good understanding of taxation will be a good basis for taxpayers to comply with taxation rules. The existence of tax law enforcement for taxpayers with good awareness is an encouragement to comply with tax obligations. It is tested with the importance of tax awareness moderation and tax law enforcement on tax compliance behaviors. 
Figure 2. Tax Compliance behaviour - tax awareness graphs

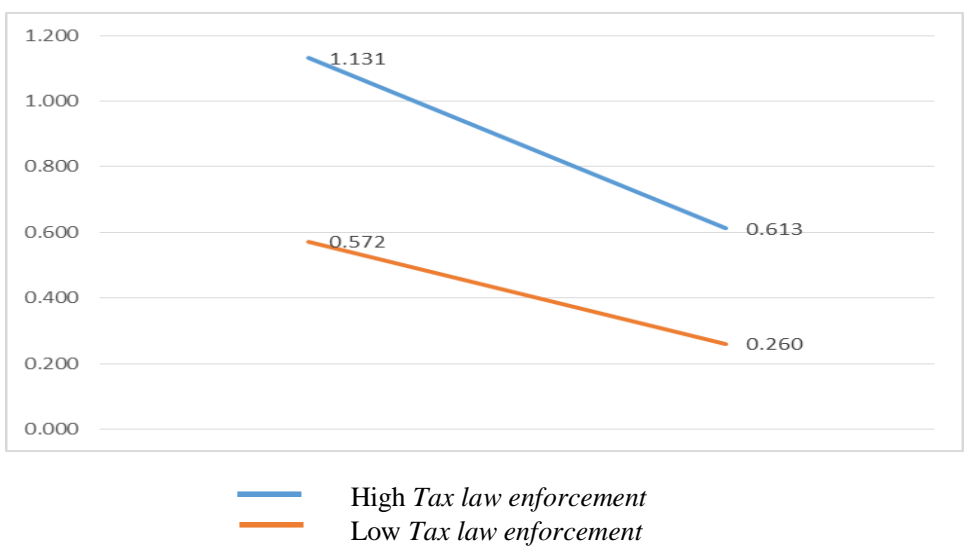

Figure 2 shows that tax law enforcement encourages a positive stance against the tax compliance behavior (tax compliance behavior), which is indicated by a higher value of tax compliance behavior when tax enforcement is strong. When law enforcement taxes are considered as high, taxpayers with good taxation awareness, the behavior of tax compliance will be strong. Conversely, when law enforcement tax is considered low, taxpayers with good taxation awareness, the behavior of tax compliance will tend to be weak. This illustrates how tax law enforcement has a role in moderate tax awareness in enhancing the behavior of tax compliance.

The Trust tax authority is a tax payer's perception of the tax Management authority, apart from taxation as a liability to WP, the existence of trust in the tax authorities will be a trigger for increasingly steady compliance of WP-compliant behaviors. In line with this study, (Kogler et al., 2013) showed that high confidence and low confidence in the tax authorities respectively increased and lowered tax compliance. Similarly, Kirchler at (Blaufus et al., 2013) argues that, when tax officials have greater ability to detect illegal taxpayers, the trust of taxpayers in the performance of officials increases. The capacity of the tax authorities that can be trusted and interact with the certainty of the law for the tax offender has a significant impact on the appropriate conduct of the taxpayer. 
Figure 3. Tax Compliance Behavior-Trust in Tax Authority Graph

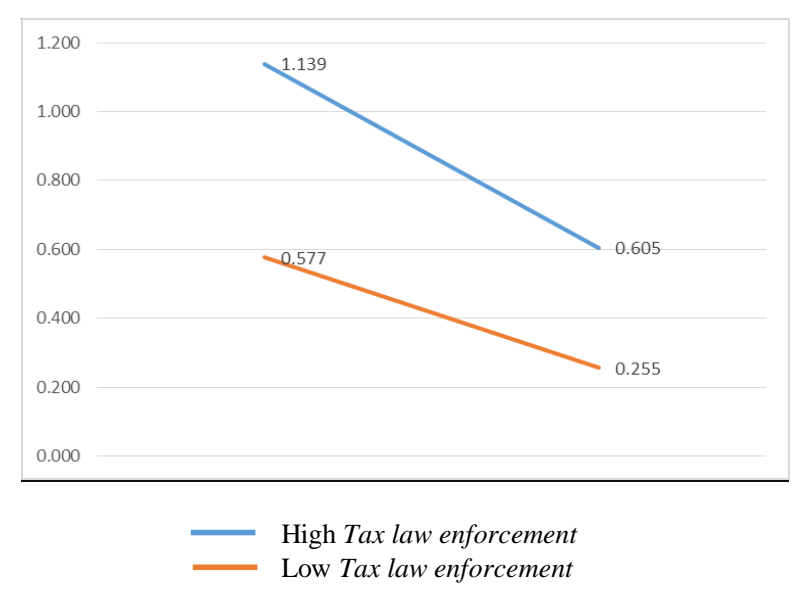

Figure 3 shows that tax law enforcement encourages a positive attitude towards the tax compliance behavior (tax compliance behavior), which is demonstrated by a higher value of tax compliance behavior when enforcement of strong tax law, as opposed to weak tax law enforcement. Tax law enforcement is considered high, so the taxpayer with the perception of the Trust in the Tax Authority is good, then the tax compliance will be strong. Conversely, when law enforcement taxes are considered weak, taxpayers with the perception of Trust in the tax authorities are good, then the behavior of tax compliance will tend to be weak. This illustrates how law enforcement taxes have a role in a moderation Trust in the tax authorities in improving the behavior of tax compliance.

\section{CONCLUSION}

A repercussive conclusion is a hypothesis that suspects the relationship between tax awareness and trust in tax authority has a significant impact on the taxpayer compliance behavior. Demkian also with the interaction between tax awareness and trust in tax authority with tax law enforcement, moderation both generate positive behavior against taxpayer compliance. Overall, the influence of tax awareness and trust in tax authority and interakasi with tax law enforcement is $39.8 \%$. This means that 39.8 percent change in taxation-compliant behavior is able to be explained by all free variables simultaneously.

Contributions and Implications. The contribution based on the results of this study is that for the Director general of taxation it is necessary to place the state income from tax as a result of a series of intermediate and long term processes and in combination with the application of tax rules and strict sanctions, by continually increasing the internal capacity of tax resources to increase the trust of taxpayer in the taxation authority. However, there are still weaknesses in this study, including the data used is cross section or data taken in the same place between X, Y, and moderation data. For this reason, future research may consider using a time element (longitudinal data) to ensure that there are changes in appropriate behavior changes based on taxpayer awareness. The use of longitudinal data will be able to detect changes in attitude and taxpayer behavior. 
The results of this research also show that the direct effect of tax enforcement has a dominant influence on the behavior of taxpayers ' compliance, with a magnitude of influence of 0.543 . This suggests that there are 2 things to do to build up the effectiveness of tax compliance formation. The first in the long run is to build a taxpayer consciousness, the second is to run consistently the legal aspects for tax offenders. The combination of the two will be very good at establishing taxpayer-compliant behaviour. Consistency with this policy builds trust in tax authorities and forms of taxpayers ' compliance.

The practical implications of the results of this research to develop appropriate behaviors are to reinforce the aspect of consciousness. Adherence to tax obligations is the result of a consistent and comprehensive set of policies. The results of this research demonstrate the role of taxpayer awareness as the initial determinant of tax compliance behaviour. Involvement of various areas of expertise to build awareness will be very important. Mapping and Roadmap need to be created to build awareness in various stages. Building this awareness can be started from an early age with the introduction of taxation at an early age, teenagers, adults and parents.

The academic implications of the results of this study are the use of moderate variables in this study using tax law enforcement which has a significant effect. Tax law enforcement is a factor outside the individual that also affects the taxpayer's behavior. Moderate variables can consider the internal aspects of taxpayers, such as gender, education, income, occupation, and may even incorporate lifestyle elements or psychology. The combination of both internal and external moderate taxpayers will enrich the academic aspects that can be developed in a more diverse direction to ensure that taxpayers are more predictable.

\section{REFERENCES}

Alhempi RR, I Ardiansyah, SY Kusumastuti, and E Endri. (2020). Tax Compliance in Income Tax Payments. International Journal of Innovation, Creativity and Change 13 (1), 356-374.

Ali, A., and Ahmad, N. (2014). Trust and Tax Compliance Among Malaysian Working Youth. International Journal of Public Administration, 37 (7), 389-396.

Alventosa, A., and Olcina, G. (2019). Tax compliance and wealth inequality. Applied Economics Letters, 1-5.

Bird, R., and Davis-Nozemack, K. (2018). Tax avoidance as a sustainability problem. Journal of Business Ethics, 151 (4), 1009-1025.

Blaufus, K., Bob, J., Hundsdoerfer, J., Kiesewetter, D., and Weimann, J. (2013). Decision heuristics and tax perception - An analysis of a tax-cut-cum-base-broadening policy. Journal of Economic Psychology, 35, 1-16.

Castro, L., and Scartascini, C. (2015). Tax compliance and enforcement in evidence from a field experiment. Journal of Economic Behavior \& Organization, 116, 65-82. https://doi.org/10.1016/j.jebo.2015.04.002.

Chan Pui Yee; M. Krishna Moorthy; William Choo. (2017). Taxpayers' perceptions on tax evasion behaviour: an empirical study in Malaysia. International Journal of Law and Management 59(3).

Devos, K. (2013). Factors influencing individual taxpayer compliance behavior. Melbourne, Australia: Springer. 
Elffers, H. (2000). But taxpayers do cooperate. In: M. van Vugt, M. Snyder, T.R. Tyler and A. Biel (eds). Cooperation in modern society: Promoting the welfare of communities, states, and organizations. London: Routledge, p.184-194.

Garcia, Filomena; Opromolla, Luca David; Vezzulli Andrea; Marques, Rafael. (2020). The effects of official and unofficial information on tax compliance. DOI: 10.1016/j.joep.2020.102265.

Ghozali, Imam. (2016). Aplikasi Analisis Multivariete Dengan Program IBM SPSS 23 (Edisi 8). Cetakan ke VIII. Semarang : Badan Penerbit Universitas Diponegoro.

Gobena, L. B., and Van Dijke, M. (2016). Power, justice, and trust: A moderated mediation analysis of tax compliance among Ethiopian business owners. Journal of Economic Psychology. 52: 24-37.

Guerra, Alice and Brooke Harrington. (2018). Attitude-behavior consistency in tax compliance. A cross-national comparison, Journal of Economic Behavior and Organization

Herryanto, M., and Toly, A. A. (2013). Effects of Taxpayer Awareness, Tax Socialization Activities, and Tax Examination on Income Tax Receipts at Surabaya Sawahan KPP. Tax and Accounting Review, 1 (1).

Indrawan, D. (2014). The Influence of Knowledge and Understanding, Effectiveness of the Taxation System, and Fiscal Services Against the Will to Pay Taxes with Awareness of Paying Taxes as Intervening Variables. (Empirical Study on Bangkinang KPP). Journal of Student Economics Online Journal, 1 (2).

Kamil, A. Putri, R. (2015). Spatial System of Creative Industry Based on Local Wisdom in the Framework of Increasing National Competitive Advantage. SNKIB II Proceeding Untar, 2 (1), 151-160.

Kogler, C., Batrancea, L., Nichita, A., Pantya, J., Belianin, A., and Kirchler, E. (2013). Trust and power as determinants of tax compliance: Testing the assumptions of the slippery slope framework in Austria, Hungary, Romania and Russia. Journal of Economic Psychology. 34: 169-180.

Law Number 16 of 2009 concerning the Fourth Amendment to Law Number 6 of 1983 concerning General Provisions and Tax Procedures.

Law of the Republic of Indonesia Number 36 Year 2008 concerning the Fourth Amendment to Law Number 7 of 1983 concerning Income Tax.

Li, T., R.M. Horton, D.A. Bader, F. Liu, Q. Sun, and P.L. Kinney. (2018). Long-term projections of temperature-related mortality risks for ischemic stroke, hemorrhagic stroke, and acute ischemic heart disease under changing climate in Beijing, China. Environ. Intl., 112, 1-9, doi:10.1016/j.envint.2017.12.006.

Lianty, R. A. M., Hapsari, D. W., and Kurnia. (2017). Taxation Knowledge, Tax Socialization, and Fiscus Services Towards Taxpayer Compliance. Journal of Contemporary Accounting Research, 9 (2).

Luttmer, E. F. P. and Singhal, M. (2014) Tax morale. Journal of Economics Perspectives, 28 (4), 68-149.

Macphee, M., Skelton-Green, J., Bouthillette, F., Suryaprakash, N., (2012). An empowerment framework for nursing leadership development: Supporting evidence, Journal of Advanced Nursing 68(1), pp. 159-169. 
Marjan, R. M. (2014). Effects of Taxpayer Awareness, Fiscus Services, and Tax sanctions on the Taxpayer Formal Compliance Level: Study at KPP Pratama Selatan Makassar). Unpublished Bachelor Thesis. Makassar: Hasanuddin University.

McKee, M., Siladke, C. A. and Vossler, C. A. (2018), "Behavioral Dynamics of Tax Compliance when Taxpayer Assistance Services are Available", International Tax and Public Finance 25, 722-756.

Melando, Nelinda and Waluyo. (2013). "The Influence of Fiscus Services, Perceptions of the Effectiveness of the Taxation System, Tax Knowledge, and Taxpayer Awareness of Personal Taxpayer Compliance (Study in Kpp Pratama Tigaraksa)". Ultima Accounting Vol 5. No.2. December 2013.

Muliari, N. K., and Setiawan, P. E. (2011). The Influence of Perception on Tax Sanctions and Taxpayer Awareness on the Compliance of Personal Taxpayer Reporting at the East Denpasar Pratama Tax Service Office. Scientific Journal of Accounting and Business, 6 (1).

Muthaloo Subramaniam, Yamunah Vaicondam, Dineswary Nadarajan, Yap Lai Leng. (2020). Sociology of Individual Voluntary Tax Compliance. International Journal of Psychosocial Rehabilitation. 24 (1).

Nashwan Bin-, Saeed; Ahmed Al-Hamedi,; Munusamy Marimuthu,; Abobakr Al-harethi,. (2020). Study on system fairness dimensions and tax compliance in the Middle East context. 18. 2020. 10.21511/ppm.18(1).2020.16.

Nurmantu, S. (2005). Introduction to Taxation - Safri Nurmantu - Google Books (3rd ed.).

Onwuka, Ifeanyi Onuka, Okoro, Blessing Chinemere, Onodugo, Vincent A. (2019). Measuring corporate governance performance beyond the financial metrics. A study based on deposit money banks in Nigeria.

Panjaitan H, Tarmizi, Daulay M, and Ginting R. (2018). "Effect of awareness against taxpayers tax compliance, small and medium enterprises in medan." International Journal of Civil Engineering and Technology, 465-475.

Regulation of the Minister of Finance of the Republic of Indonesia Number 192 / PMK.03 / 2007 concerning Procedures for Determination of Taxpayers with Certain Criteria in the Framework of Returning Overpayment of Tax Payments.

Saragih S. F. (2013). Analysis of the Influence of Tax Socialization, Fiscus Service Quality and Tax Sanctions Against Personal Taxpayer Compliance at the East Medan Pratama Tax Office (KPP). Faculty of Economics, University of North Sumatra, Medan. USU Thesis. http://repository.usu.ac.id/handle/123456789/39496. Accessed June 06, 2014. 1-65.

Slemrod Joel and Bakija Jon. (2017). Taxing Ourselves, Fifth Edition; A Citizen's Guide to the Debate over Taxes.

Sucipto. (2014). Approves the Electronic Tax Invoice Regulations. Economic NewsJanuary2014 accessed fromhttp: //wartaekonomi.co.id/berita22904/me youregulate-enforcement-invoice-electronic-tax.html (22 December 2017).

Sugeng. (2012). Effect of Effectiveness and Contribution of Land and Building Tax Revenues on Regional Revenues, Contemporary Accounting Research, 5, Institute of Accounting Study Program Publishers.

Suh, Jung-Wha, Ho-Young Lee, Arnold Edward Kuk and Hyunsoo Ryu. (2019). Effect of the trusted taxpayer designation on corporate tax avoidance behaviour. Evidence from Korea, Asian Journal of Business and Accounting, 12(2). 
Tiraada, Tryana A.M. (2013). Tax Awareness, Tax Sanctions, Fiscus Attitudes Towards WPOP Compliance in South Minahasa Regency. Journal / ISSN 2303-1174.

Vamvaka, V., Stoforos, C., Palaskas, T., and Botsaris, C. (2020). Attitude toward entrepreneurship, perceived behavioral control, and entrepreneurial intention: dimensionality, structural relationships, and gender differences. Journal of Innovation and Entrepreneurship, 9(1). doi:10.1186/s13731-020-0112-0.

Wang, Ge, Chen, Qiang, Xu, Zengyang leng, Xiaming. (2020). Can the use of government Apps shape citizen compliance? The mediating role of different perceptions of government, Computers in Human Behavior 108 (2020) 106335.

Wijaya S; Yunanda LS, Azizah WN. (2020). Study of Discount Tax Requirements for Personal Taxpayers for Increasing Tax Compliance in Indonesia. Test Engineering and Management, 83, 13553 - 13566.

Wijaya, S., and Effendi, A.S. (2020). Analysis of determinants of MSMES tax compliance in Indonesia (Case-study in working areas of Pondok aren tax office), International Journal of Advanced Science and Technology 29(6), pp. 1252-1267.

Yaude, Say and Lim Seunghoo. (2017). The Determinants of Medium Taxpayers' Compliance Perspectives: Empirical Evidence from Siem Reap Province, Cambodia. International Journal Of Public Administration. doi.org/10.1080/01900692.2019.1591447. 